\title{
Bioecology of the crab Ucides cordatus (Crustacea, Decapoda) in mangroves influenced by the Amazon River, Brazil
}

\author{
Kárlia Dalla Santa AMARAL ${ }^{1 *}$, Inácia Maria VIEIRA², Frederico Moreira OSÓRIO², \\ Joana D'arc Mauricio ROCHA ${ }^{4}$, Jô de Farias LIMA ${ }^{1}$ \\ Empresa Brasileira de Pesquisa Agropecuária - Embrapa Amapá, Rodovia Juscelino Kubitschek, km 5, n² 2600, CEP: 68903-419, Phone: +55 (96) 4009-9501. Macapá, \\ Amapá, Brazil. kdsa5@yahoo.com.br, jo.lima@embrapa.br \\ 2 Instituto de Pesquisas Científicas e Tecnológica do Estado do Amapá - IEPA, Centro de Pesquisas Zoobotânicas e Geológicas. Rodovia Juscelino Kubitschek, km 10, Fazendinha, \\ CEP: 68903-419, Phone: +55 (96) 3212-5358. Macapá, Amapá, Brazil. inaciavieira2011@gmail.com \\ ${ }^{3}$ Instituto Brasileiro do Meio Ambiente e dos Recursos Naturais Renováveis - IBAMA/RN. Avenida Alm. Alexandrino Alencar, 1399, CEP: 59.015-350, Phone: +55 (84) 3342- \\ 0410. Natal, Rio Grande do Norte, Brazil. fredosorio@gmail.com \\ ${ }^{4}$ Universidade do Estado do Amapá - UEAP. Avenida Presidente Vargas, nº 650, CEP: 68.906-970. Macapá, Amapá, Brazil. j0anar0cha@hotmail.com \\ * Corresponding Author: kdsa5@yahoo.com.br
}

\section{ABSTRACT}

The mangrove crab (Ucides cordatus) is a valuable fishery resource, overfished along the Brazilian coast. This study aimed to obtain bioecological data on this crab along the coast of the State of Amapá. Six bimonthly samplings were conducted between December 2008 and January 2010. Transects were used to estimate the density (burrows $\mathrm{m}^{-2}$ ) and population abundance (individuals $\mathrm{m}^{-2}$ ). All the animals were subjected to biometrics, with females being classified according to their stage of gonadal maturation. The mean density (1.09 burrows $\left.\mathrm{m}^{-2}\right)$ and abundance $\left(0.31\right.$ individuals $\left.\mathrm{m}^{-2}\right)$ were influenced by the climate with the highest values in summer $\left(1.17\right.$ burrows $\mathrm{m}^{-2}$ and 0.34 individuals $\left.\mathrm{m}^{-2}\right)$. The male to female ratio was $1.38: 1$ showing significant difference in the proportion of sexes. The individuals showed sexual dimorphism, with linear measurements significantly higher in males. The sampled animals also had larger carapace length and width (CL and CW) compared to crabs studied in other Brazilian states. There was a positive relationship between CW and CL and individual weight (IW) and CW for males ( ${ }^{2}$ $=0.83$ and 0.90$)$ and females $\left(\mathrm{R}^{2}=0.79\right.$ and 0.84$)$. The growth was negative allometric (CL increases to a lesser extent than $\mathrm{CW})$ for both sexes. The highest frequency of ovigerous females $(78 \%)$ and in maturation stage IV (38\%) occurred in the CW size class between 59.8 and $67.5 \mathrm{~mm}$. The peak of mature females occurred in May and August, showing a reproductive period different from those in other Brazilian states.

KEYWORDS: State of Amapá, reproductive dynamics, population structure, fishery resource

\section{Bioecologia do caranguejo Ucides cordatus (Crustacea, Decapoda) em manguezais influenciados pelo Rio Amazonas, Brasil}

\section{RESUMO}

O caranguejo-uçá (Ucides cordatus) é um valioso recurso pesqueiro, sobreexplorado ao longo do litoral brasileiro. O objetivo deste trabalho foi obter dados bioecológicos deste caranguejo em toda a costa do Estado do Amapá. Foram realizadas seis coletas de frequência bimensal, compreendidas entre os meses de dezembro de 2008 a janeiro de 2010. Por meio de transectos foram estimadas a densidade (tocas $\mathrm{m}^{-2}$ ) e a abundância (indivíduos $\mathrm{m}^{-2}$ ) populacional. Todos os animais foram submetidos à biometria, sendo somente as fêmeas, classificadas quanto ao estágio de maturação gonadal. A densidade $\left(1,09\right.$ tocas $\left.\mathrm{m}^{-2}\right)$ e a abundância $\left(0,31\right.$ indivíduos $\left.\mathrm{m}^{-2}\right)$ foram influenciadas pelo clima, sendo os maiores valores observados durante o verão $\left(1,17\right.$ tocas $\mathrm{m}^{-2}$ e 0,34 indivíduos $\left.\mathrm{m}^{-2}\right)$. A razão sexual foi de $1,38 \mathrm{M}: 1 \mathrm{~F}$, mostrando diferença significativa entre a proporção de sexos. Os indivíduos apresentaram dimorfometria sexual, com medidas lineares significativamente superiores nos machos. Os animais coletados também apresentaram maior comprimento e largura de cefalotórax (CC e LC), quando comparados aos caranguejos estudados em outros estados brasileiros. Houve relação tanto entre LC e CC, como entre peso individual (PI) e LC para machos $\left(R^{2}=0,83\right.$ e 0,90$)$ e fêmeas $\left(R^{2}=0,79\right.$ e 0,84$)$. O crescimento foi alométrico negativo (menor crescimento de CC em relação à LC) para ambos os sexos. A maior frequência de fêmeas ovígeras (78\%) e no estágio IV de maturação (38\%) pertenciam à classe de tamanho de LC 59,8 - 67,5 mm. O maior pico de fêmeas maduras ocorreu nos meses de maio e agosto, mostrando um período reprodutivo diferente de outros estados do Brasil.

PALAVRAS CHAVES: Estado do Amapá, dinâmica reprodutiva, estrutura populacional, recurso pesqueiro. 


\section{INTRODUCTION}

The mangrove crab Ucides cordatus is distributed from Florida (USA) to Santa Catarina, Southern Brazil (Coelho and Ramos 1972; Melo 1996). Its growth rate is relatively slow, making only one molting per year and reaching a life span of over 10 years (Diele 2000; Pinheiro et al. 2005). Reproduction is seasonal and the reproductive period is inversely proportional to latitude, being longer in Northern Brazil (Diele 2000; Pinheiro and Fiscarelli 2001).

Ucides cordatus is the second largest crustacean found in the Brazilian mangroves, and it is the most exploited species for human consumption (Castro et al. 2008). Some factors such as the continued increase in fishing effort, habitat degradation and the onset of diseases, contributed to this species being included in the "National List of Species of Aquatic Invertebrates and Fishes Overexploited or Threatened with Overexploitation" (IBAMA, 2004).

Although mangrove crab is widely studied along the Brazilian coast, there are few bioecology studies conducted on the Amazonian coastal zone (Diele and Smith 2006; Diele and Smith 2007; Nordhaus et al. 2009), especially in the State of Amapá (Fernandes and Carvalho 2007). Studies of this nature are extremely important to assist government agencies in developing protective measures such as: establishment of the closed season, which is the temporary interruption of the capture during the species reproduction period and setting minimum sizes and capture quotas. The regulation of crab collection is responsibility of the Brazilian Environmental Agencies. However, due to the lack of studies, the legally established closed season often does not coincide with the real time of reproduction.

The State of Amapá has a total area of 142,814,585 km² and a coastline of $598 \mathrm{~km}$. Along the coast, mangrove areas represent approximately $1.94 \%\left(2784.97 \mathrm{~km}^{2}\right)$ of State territory. Mangroves are located in the lower parts of the coastal plain, extending continuously along the coast (IEPA 2002).

Hydrodynamics of mangrove waters bordering the State of Amapá, as well as other abiotic factors, suffer profound influence of the Amazon River, which takes a northwest direction depending on the influence of the Guiana Current (IEPA 2002). Since this river has the largest water flow on the planet, it causes marked changes to the mangrove ecosystem, which are manifested in the externalization of structural and functional patterns completely different from other coastal regions in the country.

In the resident fauna of these mangroves, there is the crab U. cordatus (Linnaeus, 1763) (IEPA 2002), which along with the shrimps Macrobrachium amazonicum (Heller, 1862) and Macrobrachium carcinus (Linnaeus, 1758) are regarded the three crustacean species of greatest economic importance to the region. Therefore, this work aimed at studying some bioecological parameters of the species along the coast of Amapá in order to contribute to provision of standards for sustainable exploitation of the species, since this state includes traditional fishing communities, as well as many protected areas.

\section{MATERIALS AND METHODS}

\section{Study area}

The Atlantic Coastal Zone of the State of Amapá is located in the equatorial region and characterized by low temperature variation $\left(\right.$ mean $\left.=27^{\circ} \mathrm{C}\right)$, high relative humidity (above $\left.80 \%\right)$, high rainfall (mean $=2,500 \mathrm{~mm}$ year $\left.^{-1}\right)$, a short dry season (August to November) and a long wet season (December to July) (Vásquez and Rabelo 1999). The coastal ecosystems are strongly influenced by river discharges and macrotides, which can reach more than $10 \mathrm{~m}$. Among these ecosystems, mangroves of the region are considered the largest ones in the Brazilian coast and distributed in an almost continuous range, from the mouth of the Oiapoque River to the Amazon estuary (Costa-Neto et al. 2006).

The crab U. cordatus (Linnaeus, 1763) (Crustacea, Decapoda, Ucididae) occurs in three municipalities in the State of Amapá - Amapá, Calçoene and Oiapoque - and its capture for trading is performed in these three municipalities (Figure 1). Two sampling sites were randomly selected in each municipality, totaling six sampling areas. Mangroves in these areas are composed of two species: Rhizophora mangle L. (red mangrove) and Avicennia germinans L. (black mangrove), the latter being predominant.

\section{Bioecological characterization}

To investigate the seasonality influence on the population dynamics of $U$. cordatus, six bimonthly diurnal samplings were performed at each site in: December 2008; March, May, August and November 2009; and January 2010. Monthly samples were not performed due to the difficult access to the sampling areas that require a long period to perform each expedition. Samples were collected with permission of IBAMA and ICMBio (No. 17545-1/2009).

Three transects were performed in each sampling area with 3-m minimum spacing between them to determine the number of existing burrows, the number of burrows with inhabitants and, the number of open and closed burrows. Three squares $\left(25 \mathrm{~m}^{2}\right.$ each) were sampled in each transect. The collected data were used to estimate the abundance and density existing in the studied areas. The number of individuals collected (individuals $\mathrm{m}^{-2}$ ) was used to determine the abundance, while data on the number of inhabited 




Figure 1 - Municipalities in the State of Amapá (Amapá, Calçoene and Oiapoque) with occurrence of the crab Ucides cordatus, showing the mangroves, protected areas (Cabo Orange National Park and Maracá-Jipioca Ecological Station) and collection areas.

burrows, empty burrows and capped burrows (total burrows $\mathrm{m}^{-2}$ ) were used in the density calculation.

The animal capture was performed manually by hands. After collection, the specimens were washed and packed in polyethylene bags for transport to appropriate location to perform the biometrics. Subsequently, the animals were stored ice coolers to induce them to a lethargic stage, thus facilitating the acquisition of biometric data (sex, weight and carapace's linear measurements), as well as determining the gonadal maturation stage of females. The evaluation criteria established by Mota Alves (1975) were used for determining the gonadal maturation of females. The maturation stages were not identified in males, since the analyses were carried out in the field and did not allow more accurate observation of the gonads.

The sexual characterization of individuals was made macroscopically because the animals showed evident sexual dimorphism in the abdomen. The statistical significance of sex ratio on stocks composition was calculated by using the Chi-square test $\left(x^{2}\right)$ for each month and the total period of data collection. 
The individual weight (IW) was determined on analytical balance $(0.1 \mathrm{~g}$ accuracy). Linear measurements $(\mathrm{mm})$ such as carapace length and width ( $\mathrm{CL}$ and $\mathrm{CW}$ ) were determined with steel caliper $(0.1 \mathrm{~mm}$ accuracy), according to the methodology of Pinheiro and Fiscarelli (2001). During weighing, the individuals without any of the claws were discarded. Crabs without some of the pereiopods had the weight of the pereiopod symmetrical to that one lost added to their total weight. The $\mathrm{t}$ test was used to compare biomass data, CL and CW between males and females at $0.05 \%$ probability. The ratios between linear measures of carapace width and length (CW $x \mathrm{CL})$ for males and females were set to the linear equations $y=a+b x$. Ratios between carapace width and individual weight (CW $\mathrm{x}$ IW) were set to the exponential equations $\mathrm{y}=\mathrm{Ax}^{\mathrm{b}}$. Regression analysis by power function was used to check for the growth types through the b value (Hartnoll 1978). Regarding CW x CL, the growth types may be: Isometric $(b=1)$, positive allometric $(b>1)$ or negative allometric $(b<1)$. Concerning to $C W x I W$, growth can be isometric $(b=3)$, positive allometric $(b>3)$ or negative allometric $(b<3)$.

\section{RESULTS}

The density (total burrows $\mathrm{m}^{-2}$ ) was higher than abundance (individuals $\mathrm{m}^{-2}$ ) in January, March, August and November (Figure 2).The mean density (1.09 burrows $\mathrm{m}^{-2}$ ) and mean abundance $\left(0.31\right.$ individuals $\left.\mathrm{m}^{-2}\right)$ were low in the study period. The highest values of individuals ( 0.49 individuals $\mathrm{m}^{-2}$ ) and burrows ( 1.45 burrows $\mathrm{m}^{-2}$ ) were found in August, November and December, when there is low rainfall (Figure 2). The mean density and mean abundance in the dry season ( 1.17 burrows $\mathrm{m}^{-2}$ and 0.34 individuals $\mathrm{m}^{-2}$ ) were higher than those found in the wet season (1.01 burrows $\mathrm{m}^{-2}$ and 0.28 individuals $\mathrm{m}^{-2}$ ).

A total of 859 crabs of the species Ucides cordatus, 498 males and 361 females, were collected for bioecological studies in six areas along the coast of Amapá from December 2008 to January 2010 (bimonthly samplings). According to the the Chi-square test for $\mathrm{c}^{2}(0.05)=3.84$, there was no significant difference between the frequency of males and females in

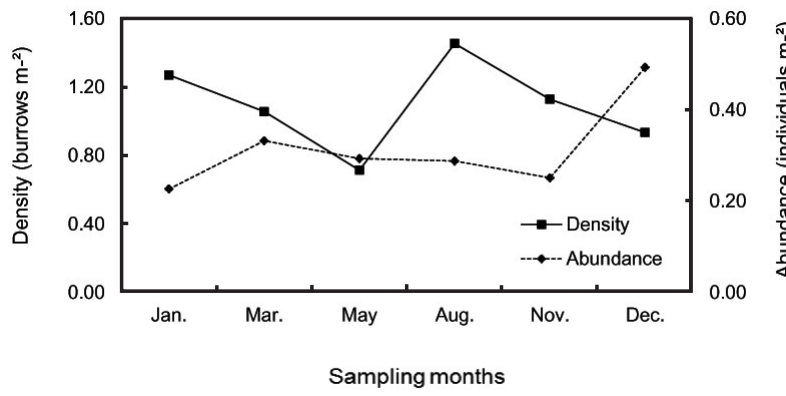

Figure 2 - Density and abundance distributions for Ucides cordatus during the sampling months
March $\left(c^{2}=3.16\right)$, November $\left(c^{2}=0.7\right)$ and December $\left(c^{2}=\right.$ 1.32). Regarding the total individuals collected $\left(c^{2}=21.8\right)$, there was a significant difference for sex ratios in January $\left(c^{2}\right.$ $=15.86)$, May $\left(c^{2}=5.54\right)$ and August $\left(c^{2}=13.78\right)$.

Mean values obtained from the linear measurements and weights showed that the collected animals had larger carapace width $(64.35 \mathrm{~mm})$ and length $(49 \mathrm{~mm})$ and heavier weight $(125.3 \mathrm{~mm})$. According to the statistical analysis $(t$-test $)$, all variables were significantly different for males and females, as shown by the $P$ values $(\mathrm{a}=0.05)$ (Table 1$)$. Thus, males had heavier weight, larger carapace length $(\mathrm{CL})$, width $(\mathrm{CW})$ and higher height values $(\mathrm{CH})$ than females, which clearly shows the dimorphometrics between sexes (Table 1).

Ratios between linear measurements of males and females showed a relationship between carapace length and width, which was stronger for male individuals $\left(\mathrm{R}^{2}=0.8319\right)$ (Figure $3)$. Regarding the growth type (CW $\times \mathrm{CL})$, the $\mathrm{b}$ values of males $(b=0.99)$ and females $(b=0.83)$ indicated negative allometric growth tending to the isometry.

Ratios between carapace width and individual weight (CW $x$ IW) was stronger for males $\left(R^{2}=0.9055\right)$ (Figure 3$)$. The $\mathrm{CW} \times \mathrm{IW}$ equations for males $(\mathrm{b}=2.7)$ and females $(\mathrm{b}=2.4)$ showed $\mathrm{b}$ constant value less than 3 and indicated negative allometric growth.

Most females collected (37.5\%) showed CW between 59.8 and $67.5 \mathrm{~mm}$. As for males, the highest frequency (28.9\%) for $\mathrm{CW}$ class was $67.5-75.1 \mathrm{~mm}$ (Figure 4). The low number of crabs in smaller size classes (juveniles and small adults found in the mangroves) is related to the difficulty of finding their burrows and due to the method for animal capture used by the collectors.

Regarding the reproduction, the highest frequency of ovigerous females $(78 \%)$ and those on stage IV of maturation (38\%) were found in CW class 59.8 to $67.5 \mathrm{~mm}$. Most females were sexually mature in the late May and early August due to the higher percentage of females with dark brown and wine colored ovaries (Figure 5). In addition, 100\% of the ovigerous females were found in August, suggesting that the reproductive peak occurs in the last quarter of wet season and in the first quarter of dry season.

\section{DISCUSSION}

The populations of Ucides cordatus showed lower density values than those determined for some States from the North and Northeast regions of Brazil. This fact may be related to the environmental characteristics of the study areas, such as vegetation structure and composition (Pedersen et al. 2003), freshwater influence (Wolcott 1988), sediments (Frusher et al. 1994) and topography (Blankensteyn et al. 1997). Mean densities of 6.0 (Almeida and Melo 1996) and 1.65 burrows 
Table 1 - Carapace linear measurements and individual weights of males and females of Ucides cordatus from the coast of Amapá.

\begin{tabular}{|c|c|c|c|c|c|c|c|c|}
\hline \multirow{3}{*}{ Values } & \multicolumn{6}{|c|}{ Carapace measurements (mm) } & \multirow{2}{*}{\multicolumn{2}{|c|}{ Weight (g) }} \\
\hline & \multicolumn{2}{|c|}{ Length } & \multicolumn{2}{|c|}{ Width } & \multicolumn{2}{|c|}{ Height } & & \\
\hline & Male & Female & Male & Female & Male & Female & Male & Female \\
\hline Mean $( \pm S D)$ & $51.9( \pm 8.0)$ & $46.1( \pm 5.5)$ & $69.1( \pm 11.2)$ & $59.6( \pm 7.7)$ & $27.5( \pm 11.3)$ & $23.5( \pm 3.6)$ & $155.4( \pm 64.8)$ & $95,2( \pm 28.8)$ \\
\hline Minimum & 19.4 & 28.1 & 19.0 & 15.2 & 13.8 & 12.3 & 11 & 21 \\
\hline Maximum & 72.2 & 62.8 & 96.5 & 78.6 & 55.0 & 48.9 & 372 & 195 \\
\hline $\mathrm{N}$ & 498 & 368 & 498 & 360 & 497 & 361 & 342 & 247 \\
\hline$P\left({ }^{3} 0,05\right)$ & \multicolumn{2}{|c|}{$9.16 \times 10^{-34}$} & \multicolumn{2}{|c|}{$3.0 \times 10^{-44}$} & \multicolumn{2}{|c|}{$3.9 \times 10^{-13}$} & \multicolumn{2}{|c|}{$1.43 \times 10^{-43}$} \\
\hline
\end{tabular}

$\mathrm{SD}=$ Standard Deviation

$\mathrm{m}^{-2}$ (Diele 2000) were recorded in Northern Brazil (Pará State). In the Northeast, densities values were 5.58 in Maranhão (Castro et al. 2008); 1.26 in Rio Grande do Norte (Ivo et al. 2000) and 1.70 burrows $\mathrm{m}^{-2}$ in Paraíba (Alves and Nishida 2004). Mean densities were higher than the abundance values in most months, suggesting that the same individual may be occupying more than one burrow for shelter. In addition, marks left by predators on the edge of the burrows indicate that some of these burrows may be empty due to predation, anthropogenic actions, or may have been caused by other animals such as raccoons (Procyon sp.). Reproductive migration can also influence the abundance; however, this phenomenon was not observed in this study.

The abundance and density were associated in some studies with reduced forest fragment size and/or increased pressure on capture species of fish, mollusks and crustaceans in other parts of the world (Oribhabor and Udo 2011). According to Lara (2003), mangroves in the Amazon coast are well preserved due to the lower anthropogenic pressure on this region. However, with increasing habitat destruction and increased overexploitation of fishery stocks, those species with low population densities are more likely to be impacted.

In addition, mean density and mean abundance were higher in the dry season months than in those of wet season. Glaser and Diele (2004) reported that the number of animals captured by gatherers in Caeté, Pará State during the rainy season was lower. One explanation for the significant reduction in the production of $U$. cordatus in wet season is mainly due to the individuals' behavior of crawling into the deepest parts of the galleries, making them difficult to collect (Oliveira et al. 2007) as observed in this study. The climate influence on other population parameters, such as density, may also be corroborated by other studies. In the State of Maranhão (Castro 1986) changes were observed in the mean density of crabs between the rainy and dry seasons. However, in another work performed on the island of São Luis and the eastern coast of the State of Maranhão, Castro et al. (2008) observed equivalent densities for both periods.
Once the State law of Amapá prohibits collecting females during all months of the year, it was expected that the frequency of male individuals was lower than that of females. However, the total number of males collected exceeded the number of females. The same pattern occurred in December, May and August. In the States where the capture of females is allowed, except for the closed season (reproduction period), the greater capture of males may be related to their larger size. Glaser and Diele (2004) found that market demand for females in the estuary Caeté, Pará State is very low and only male individuals are landed in the local ports. A study in the estuary of Ceará River, located in the municipality of Caucaia, Ceará State with a great tradition of crab consumption and whose stocks are almost exhausted, showed the predominance of females over males (Alcântara-Filho 1978). The same situation occurred in Pernambuco with the predominance of females in the mangroves of Rio Formoso Estuary (Botelho et al. 1999). Araújo and Calado (2008) indicated a numerically balanced population in Alagoas with no significant difference between the number of males and females. In this work, the same situation was found in November, December and March, despite the statistical analyses showing a significant difference between the total frequency of males and females.

Another difference observed between males and females was regarding the linear measurements studied (height, width and length of the carapace - CH, CW and CL) and the weight of individuals. In São Paulo (Pinheiro and Fiscarelli 2009), Santa Catarina (Wunderlich et al. 2008), Piauí (Ivo et al. 1999) and Rio Grande do Norte (Vasconcelos et al. 1999) males were larger and heavier than females. On the other hand, Araujo and Calado (2008) found no significant difference between these parameters in Alagoas.

Overall, males and females collected in the State of Amapá had larger CW and CL compared to crabs studied in the States of Ceará (Alcântara-Filho 1978), Maranhão (Castro 1986), Pernambuco (Botelho et al. 1999), Piauí (Ivo et al. 1999), Rio Grande do Norte (Vasconselos et al. 1999), Paraná (Dalabona et al. 2005), Pará (Diele et al. 2005) and Alagoas (Araújo and Calado 2008). The fact of the Amapá 

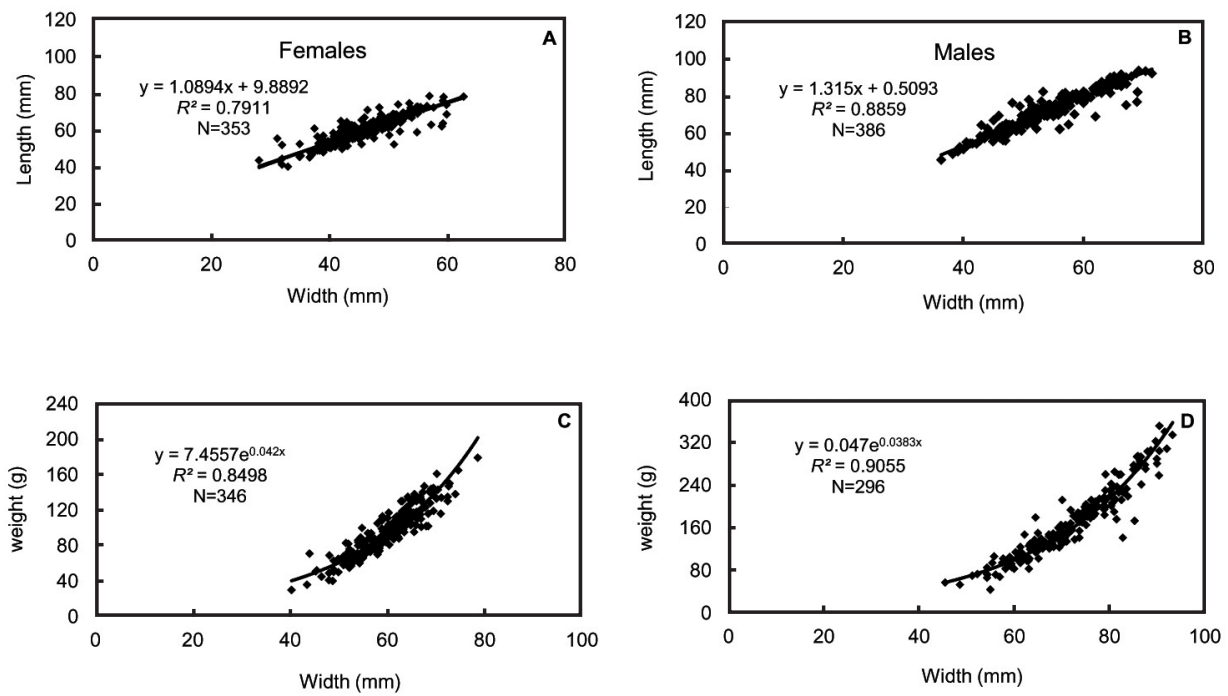

Figure 3 - Relationship between carapace width and length for females (A) and males (B); and the relationship between carapace width and individual weight for females (C) and males (D) of the crab Ucides cordatus collected in the State of Amapá.

State having population stocks consisting of large individuals may be related in part to the anthropogenic factors. The tradition of consuming the species in the North of Brazil is not as intense as in the Northeast, which accounts for the highest percentage of captures in the country. In the latter, the closed season coincides with the period of most intense tourism, being demanded a lot of animals to supply bars and restaurants. Amapá is still a sparsely populated state and where tourism is underdeveloped, which may also be contributing to the maintenance of large individuals. Moreover, the isolation of areas where $U$. cordatus occurs make capture more difficult in some way.

In the ratios CW $x$ CL and CW $x$ IW of males and females collected in this study, the samples distribution showed a straight line trend, therefore showing a relationship between the parameters investigated. Considering both CW $\mathrm{x}$ CL and CW $\mathrm{x}$ IW (males and females), the growth type was characterized as negative allometric. Regarding the CW $\mathrm{x}$ CL, the animals showed negative allometric (males) and isometric (females) growth types in Ceará (Leite et al. 2006) and Paraná (Dalabona et al. 2005). This indicates that the carapace length increases to a lesser extent in males and with the same proportion in females. In São Paulo (Pinheiro and Hattori 2006), Rio de Janeiro (Passos and Di-Beneditto 2005) and Alagoas (Araújo and Calado 2008), negative allometry was detected for both sexes. Concerning to the ratio IW $x \mathrm{CW}$, studies by Pinheiro and Fiscarelli (2009) indicated isometric growth for males and negative allometry for females.

Regarding the reproduction, the highest frequency of ovigerous and mature (stage IV) females was found in the CW size class 59.8 - $67.5 \mathrm{~mm}$, but mature females also occurred in the smallest size class $(14-21.6 \mathrm{~mm})$. Moreover, most females were sexually mature in the late May and early August. In the Northeast, Alcântara-Filho (1978) and Costa (1979) described the reproductive period occurring from December to May, although shorter periods - from January to May (Mota-Alves 1975) and January to March (Castro 1986) - have also been described in the literature. Branco (1993) reported the mating of species in January to the South of Brazil only based on observations on the reproductive behavior of individuals. In Santa Catarina, Wunderlich et al. (2008) observed females with mature gonads during five months of the year (November to March), with two major annual incidences in November (95.2\%) and February (18.2\%).

According to Sastry (1983), crustaceans can reproduce during all months of the year (continuous pattern) or be restricted to a few months, where environmental conditions are more favorable (discontinuous or seasonal pattern). Sastry (1983) and Pinheiro and Fransozo (2002) report that $U$. cordatus has seasonal reproduction, once the record of females with mature gonads occurs during only five months of the year (November to March), including the occurrence of ovigerous females (December and January). Such information corroborates Diele (2000) in the State of Pará, who shows the reproduction of this species restricted to the rainy season, following similar pattern to that of other semi-terrestrial and terrestrial crabs already studied (Henmi and Kaneto 1989; Adamczewska and Morris 2001). Therefore, the reproductive period of crabs collected in the State of Amapá is different from those in the aforementioned states. 


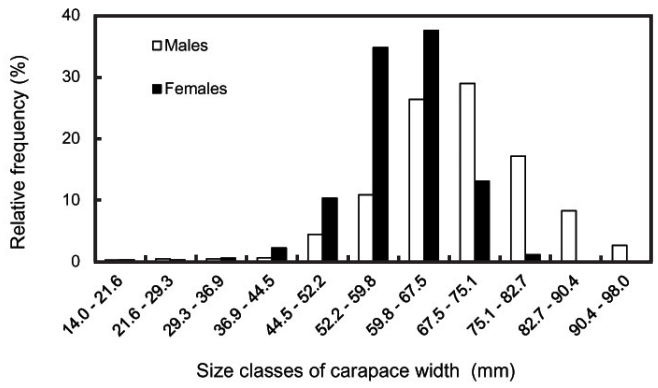

Figure 4 - Size classes of carapace width for males and females of Ucides cordatus.

\section{ACKNOWLEDGMENTS}

Funding was provided by Empresa Brasileira de Pesquisa Agropecuária (EMBRAPA). The authors thank the environmental analysts and technicians from the "Instituto Brasileiro do Meio Ambiente e dos Recursos Naturais Renováveis - IBAMA" and from the "Instituto Chico Mendes de Conservação da Biodiversidade - ICMBio" for their logistical support offered to this work. Also, we thank Frederico Fonseca Galvão de Oliveira for the map confection and the crab collectors for their assistance with the fieldwork.

\section{REFERENCES}

Adamczewska, A. M.; Morris, S. 2001. Ecology and behavior of Gecarcoidea natalis, the Christmas Island red crab, during the annual breeding migration. Biological Bulletin, 200: 305-320.

Alcântara-Filho, P. 1978. Contribuição ao estudo da biologia e ecologia do Caranguejo-uçá, Ucides cordatus cordatus (Linnaeus, 1763) (Crustacea, Decapoda, Brachyura), no manguezal do Rio Ceará (Brasil). Arquivos de Ciências do Mar, 18: 1-41.

Almeida, L. F.; Mello, C. F. 1996. Estudo preliminar da biologia e ecologia do caranguejo-uçá, Ucides cordatus (Crustacea, Decapoda, Brachyura) no Município de Curuçá (PA) - Uma contribuição ao manejo de recursos em áreas de manguezais. In Anais da 3a Reuniāo da SBPC. Ecossistemas Costeiros: do conhecimento à gestấo, $\mathrm{p}$ 499. Sociedade Brasileira para o Progresso da Ciência-SPBC, Florianópolis, SC, Brazil.

Alves, R. R. N.; Nishida, A. K. 2004. Population structure of the mangrove crab Ucides cordatus (Crustacea: Decapoda; Brachyura) in the estuary of the Mamanguape River, Northeast Brazil. Tropical Oceanography, 32: 23-37.

Araújo, M. S. L.; Calado, T. C. S. 2008. Bioecologia do CaranguejoUçá Ucides cordatus (Linnaeus) no Complexo Estuarino Lagunar Mundáu/Manguaba (CELMM), Alagoas. Brasil. Revista da Gestão Costeira Integrada, 8: 169-181.

Blankensteyn, A.; Cunha- Filho, D.; Freire, A. S. 1997. Distribuição, estoques pesqueiros e conteúdo protéico do caranguejo do mangue Ucides cordatus (L. 1763) (Brachyura Ocypodidae) nos manguezais da Baía das Laranjeiras e adjacências, Paraná, Brasil. Arquivos de Biologia e Tecnologia, 40: 331-349.

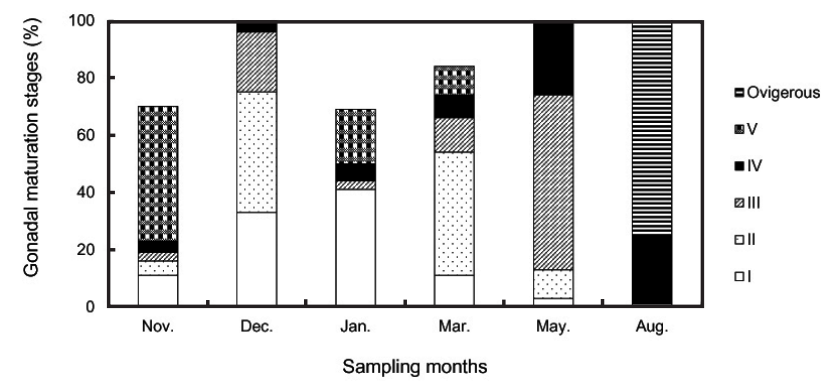

Figure 5 - Relative frequency for the female different gonadal maturation stages (Ovigerous; I-V) of Ucides cordatus during the sampling months.

Branco, J. O. 1993. Aspectos Bioecológicos do Caranguejo Ucides cordatus cordatus (Linnaeus, 1763) (Crustacea, Decapoda) do Manguezal do Itacurubi, Santa Catarina, BR. Arquivos de Biologia e Tecnologia, 36: 133-148.

Botelho, E. R. O.; Dias, A. F.; Ivo, C. T. 1999. Estudo sobre a biologia do caranguejo-uçá, Ucides cordatus (Linnaeus, 1763), capturado nos estuários dos Rios Formoso (Rio Formoso) e Ilhetas (Tamandaré), no Estado de Pernambuco. Boletim Técnico Científico do CEPENE, 7: 117-145.

Castro, A. C. L. 1986. Aspectos Bio-Ecológicos do Caranguejo-uçá, Ucides cordatus cordatus (Linnaeus, 1763), no estuário do Rio dos Cachorros e Estreito do Coqueiro, São Luís - MA. Boletim do Laboratório de Hidrobiologia, 7: 7-26.

Castro, A. C. L.; Correia, M. M. F., Nascimento, A. R., PiedadeJúnior, R. N., Gama, L. R. M., Sousa, M. M., Sena, A. C. S., Sousa, R. C. C. 2008. Aspectos bioecológicos do caranguejo-uçá (Ucides cordatus cordatus, L.1763) (Decapoda, Brachyura) nos manguezais da ilha de São Luís e litoral oriental do Estado do Maranhão, Brasil. Amazônia: Ciência \& Desenvolvimento, 3: $17-36$.

Coelho, P. A.; Ramos, M. A. 1972. A constituição e a distribuiçáo da fauna de decápodes do litoral leste da América do Sul, entre as latitudes $5^{\circ} \mathrm{N} \mathrm{e} 39^{\circ} \mathrm{S}$. Trabalhos Oceanográficos da Universidade Federal de Pernambuco, 13: 133-236.

Costa, R. S. 1979. Bioecologia do caranguejo-uçá, Ucides cordatus (Linnaeus, 1763) - Crustáceo, Decápode - no Nordeste Brasileiro. Boletim Cearense de Agronomia, 20: 1-74.

Costa-Neto, S. V.; Senna, C. S. F.; Coutinho, R.S. 2006. Vegetação das Áreas Sucurijú e Região dos Lagos no Amapá. In: CostaNeto, S.V. (Ed.). Inventário Biológico das Áreas do Sucurijú e Região dos Lagos, no Amapá. IEPA. Macapá, AP, Brazil, 79 p.

Dalabona, G.; Silva, J. L.; Pinheiro, M. A. A. 2005. Size at morphological maturity of Ucides cordatus (Linnaeus, 1763) (Brachyura, Ocypodidae) in the Laranjeiras Bay, Southern Brazil. Brazil. Brazilian Archives of Biology and Technology,_48: 139-145.

Diele, K. 2000. Life history and population structure of the exploited mangrove crab Ucides cordatus cordatus (L.) (Decapoda: Brachyura) in the Caeté estuary, North Brazil. Zentrum für Marine Tropenökologie - ZMT. Bremen, 2000, 130 p.

Diele, K.; Koch, V.; Saint-Paul, U. 2005. Population structure, catch composition and CPUE of the artisanally harvested mangrove crab Ucides cordatus (Ocypodidae) in the Caeté estuary, North 
Brazil: Indications for over fishing? Aquatic Living Resources, 18: 169-178.

Diele, K.; Smith, D.J.B. 2006. Salinity tolerance of northern Brazilian mangrove crab larvae, Ucides cordatus (Ocypodidae): Necessity for larval export? Estuarine, Coastal and ShelfScience, 68: 600-608.

Diele, K.; Simith, D. J. B. 2007. Effects of substrata and conspecific odour on the metamorphosis of mangrove crab megalopae, Ucides cordatus (Ocypodidae). Journal of Experimental Marine Biology and Ecology, 348: 174-182.

Fernandes, M. E. B.; Carvalho, M. L. 2007. Bioecologia de Ucides cordatus Linnaeus, 1763 (Decapoda: Brachyura) na costa do Estado do Amapá. Boletim do Laboratório de Hidrobiologia, 20: 15-22.

Frusher, S.D.; Giddins, R.I.; Smith, T.J. 1994. Distribution and abundance of grapsid crabs (Grapsidae) in a mangrove estuary: effects of sediment characteristics, salinity tolerances and osmoregulatory ability. Estuaries, 17: 647-654.

Glaser, M.; Diele, K. 2004. Asymmetric outcomes: assessing central aspects of the biological, economic and social sustainability of a mangrove crab fishery, Ucides cordatus (Ocypodidae), in North Brazil. Ecological Economics, 49: 361-373.

Hartnoll, R. G. 1978. The determination of relative growth in Crustacea. Crustaceana, 34: 281-293.

Henmi, Y.; Kaneto, M. 1989. Reproductive ecology of three ocypodid crabs I. The influence of activity differences on reproductive traits. Ecological Research, 4: 17-29.

IBAMA - Instituto Brasileiro do Meio Ambiente e dos Recursos Naturais Renováveis. 2004. Instrução Normativa No 5.

IEPA - Instituto de Pesquisas Científicas e Tecnológicas do Estado do Amapá. Macrodiagnóstico do Estado do Amapá: primeira aproximação do ZEE. Macapá: IEPA - ZEE, 2002, 140 p.

Ivo, C. T. C.; Dias, A. F.; Mota, R. I. 1999. Estudo sobre a biologia do caranguejo-uçá, Ucides cordatus cordatus, (Linnaeus, 1763), capturado no delta do Rio Parnaíba, Estado do Piauí. Boletim Técnico Científico do CEPENE, 7: 53-84.

Ivo, C. T. C.; Dias, A. F.; Botelho, E. R. O.; Mota, R. I.; Vasconcelos, J. A.; Vasconcelos, E. M. S. 2000. Caracterização das populaçôes de caranguejo-uçá, Ucides cordatus (Linnnaeus, 1763), capturadas em estuários do nordeste do Brasil. Boletim Técnico Científico do CEPENE, 8: 7-42.

Lara, R.J. 2003. Amazonian mangroves - A multidisciplinary case study in Pará State, North Brazil: Introduction. Wetlands Ecology and Management, 11: 217-221.

Leite, M. M. L.; Fonteles-Filho, A. A.; Silva, J. R. F.; Cardoso, N. S. 2006. Análise do crescimento alométrico no caranguejo-uçá, Ucides cordatus (Decapoda: Ocypodidae), no Estuário do Rio Coreaú, Camocim, Ceará. Arquivos de Ciências do Mar, 39: 93-98.

Melo, G. A. S. 1996. Manual de Identificação dos Brachyura (caranguejos e siris) do Litoral Brasileiro. Plêiade/FAPESP Press, São Paulo, 1996, 603 p.
Mota-Alves, M. I. 1975. Sobre a produção do caranguejo-uçá, Ucides cordatus (Linnaeus), em mangues do estado do Ceará (Brasil). Arquivos de Ciências do Mar, 15: 84-91.

Nordhaus, I.; Diele, K.; Wolff, M. 2009. Activity patterns, feeding and burrowing behaviour of the crab Ucides cordatus (Ucididae) in a high intertidal mangrove forest in North Brazil. Journal of Experimental Marine Biology and Ecology, 374: 104-112.

Oribhabor, B. J.; Udo, M. T. 2011. Impact of mangrove forest destruction on the fisheries resources of the Niger Delta, Nigeria. Nature \& Faune, 25: 72-76.

Oliveira, M. A.; Schmidt, A. J.; May, M.; Araújo, S. M. B.; Ferreira, H. M. 2007. Levantamento da produçáo pesqueira de caranguejo-uçá (Ucides cordatus) na Reserva Extrativista de Canavieiras - BA. In: Congresso Latino-Americano de Ciências do Mar - XII COLACMAR. Florianópolis, SC, Brazil.

Passos, C. A.; Di-Beneditto. A. P. M. 2005. Captura comercial do caranguejo-uçá, Ucides cordatus (L., 1763), no Manguezal de Gargaú, RJ. Biotemas, 18: 223-231.

Pedersen C.; Everett, B.; Fielding, P.; Robertson, W. D.; Kyle, R. 2003. Subsistence utilization of the crab Neosarmatium meinerti in the Kosi Lakes ecosystem, KwaZulu-Natal, South Africa. African Zoology, 38:15-28.

Pinheiro, M. A. A.; Fiscarelli, A. G. 2001. Manual de Apoio à Fiscalização - Caranguejo-Uçá (Ucides cordatus). Itajaí: UNESP: CEPSUL: IBAMA, 2001, 43 p.

Pinheiro, M. A. A.; Fiscarelli, A. G.; Hattori, G. Y. 2005. Growth of the mangrove crab Ucides cordatus (Brachyura, Ocypodidae). Journal of Crustacean Biology, 25: 293-301.

Pinheiro, M. A. A.; Fiscarelli, A. G. 2009. Length-weight relationship and condition factor of the mangrove crab Ucides cordatus (Linnaeus, 1763) (Crustacea, Brachyura, Ucididae). Brazilian Archives of Biology and Technology, 52: 397-406.

Pinheiro, M. A. A.; Fransozo, A. 2002. Reproduction of the speckled swimming crab Arenaeus cribrarius (Brachyura: Portunidae), in the southern coast of Brazil. Journal of Crustacean Biology, 22: 416-428.

Pinheiro, M. A. A.; Hattori, G.Y. 2006. Relative growth of the mangrove crab Ucides cordatus (Crustacea, Brachyura, Ocypodidae) at Iguape (SP), Brazil. Brazilian Archives of Biology and Technology, 49: 813-823.

Sastry, A. N. 1983. Ecological aspects of reproduction. In: F.J. Vernberg, and W.B. Vernberg (Eds). The Biology of Crustacea. Environmental adaptations. New York, Academic Press. p. $179-270$.

Vasconcelos, E. M. S.; Vasconcelos, J. A.; Ivo, C. T. C. 1999. Estudo sobre a biologia do caranguejo-uçá, Ucides cordatus cordatus (Linnaeus, 1763), capturado no estuário do Rio Curimatau (Canguaretama) no estado do Rio Grande no Norte. Boletim Técnico Científico do CEPENE, 7: 85-116.

Vásquez, M. P.; Rabelo, F.G. 1999. Sustainable management of an Amazonian Forest for timber production: a myth or reality? Plec News and Views, 12: 20-28. 


\section{ACTA}

Wolcott, T. 1988. Ecology. In: Burggren WW, McMahon BR (eds) Biology of land crabs. Cambridge University Press. New York, USA. p. 55-96

Wunderlich, A. C.; Pinheiro, M. A. A.; Rodrigues, A. M. T. 2008. Biologia do caranguejo-uçá, Ucides cordatus (Crustacea: Decapoda: Brachyura), na Baía da Babitonga, Santa Catarina, Brasil. Revista Brasileira de Zoologia, 25: 188-198.

Recebido em 28/02/2013

Aceito em 01/08/2013 
